\section{British physicians brood on HIV testing and 'designer children'}

\section{London}

Physicians in Britain agreed last week only for clinical reasons and with their consent. According to this decision, physicians testing for the virus without the patient's consent must believe it to be in the patient's best interest, and be prepared to defend their actions in a court of law and before the General Medical Council.

In passing this resolution at its annual conference last week, the British Medical Association (BMA) reversed last year's decision to allow testing for HIV without necessarily seeking patients' consent. Lawyers advised the BMA that this could lead to legal action against doctors.

At the same time, last week's conference resolved to promote anonymous screening for HIV in order to gather more information about the true extent of infection in Britain. Otherwise, physicians fear that the public will become increasingly immune to warnings about AIDS. But they'agreed that screening would have to be done in such a way that tests could not be traced to an individual; the BMA criticized a screening programme of pregnant women at St Bartholomew's Hospital, London, on the grounds that it is small enough for individuals to be identified.

The conference also decided that, in order to slow down the spread of the virus, condoms should be made freely available in prisons, despite the legal dilemma this presents for the government: homosexual acts are legal only in private and prisons do not offer privacy.

The conference was also concerned at the amount of personal information physicians are being required to give to insurance companies. Dr John Dawson, head of the BMA's professional division, said that more companies were insisting on tests for HIV before agreeing to mortgages of more than $£ 50,000$. The conference resolved that patients should see the questions that doctors are to be asked on a medical report and sign their consent.

The BMA conference also sanctioned guidelines to physicians on the implications of genetic engineering. Dr Ian Jessiman spoke of the possible dangers of allowing developments in genetics to proceed without regulation. While genetic substitution could bring substantial benefits, he said, it could also have drawbacks, including the production of what he called 'designer children' with pre-selected characteristics. He also warned that as testing for genetic defects became more sophisticated, people might demand abortion for increasingly trivial reasons. And he warned of the ecological implications of the accidental release of dangerous viruses into the environment. Dr Dawson added that it was important to consider now what the future implications of interfering with the human gene pool might be.

The BMA is also to investigate the effects of pesticides on human health. The conference agreed that more information is necessary on the effects of long-term exposure to low levels of pesticides, on which the investigation will concentrate.

Christine McGourty that patients should be tested for the human immunodeficiency virus (HIV)

\section{Renewed efforts by French haemophiliacs on compensation}

\section{Paris}

THE death from AIDS last week of the president of the French Hemophiliac Association, André Leroux, aged 49, adds further poignancy to the association's unsuccessful demands for compensation for haemophiliacs contaminated with the human immunodeficiency virus (HIV) following treatment with blood products. France has so far not decided what its position should be.

Since 1985, France has screened all blood offered for transfusion for the presence of antibodies to HIV. But current health ministry estimates show that at least 226 people were infected following transfusions before these measures were introduced. In addition, an estimated 1,500 (almost half) of the country's haemophiliacs have been infected by con- taminated blood products and 50 have already died from AIDS.

Before the recent change of government, the former health minister, Michèle Barzach, defended the position that the ministry is not legally bound to compensate individuals infected through contaminated blood or blood products. As such treatments are not classified as drugs, and so no charge of negligence can be filed, the question of liability remains unresolved. In the meantime, Barzach had promised to give $F F 300,000(£ 28,600)$ to the French Hemophiliac Association to help members suffering from AIDS, but this money has so far not been released.

In France, when the national haemophiliac association initially approached government, few seropositive members

\section{Bavarian AIDS ruling will go to appeal \\ Munich}

A CONTROVERSial ruling in a bizarre court case seems to be a new departure in the West German legal system's approach to AIDS. To the dismay of Bavarian hardliners, the decision of a district court (Amtsgericht) in the city of Kempten on 1 July may make it more difficult to prosecute AIDS virus carriers who purposefully transmit the virus.

The case involves a 29-year-old Italian HIV carrier, who was accused of "attempting to inflict dangerous bodily harm" by having unprotected sexual intercourse (without using a condom) with his 16-yearold German girlfriend. The girl was aware of his condition and was not infected, although the couple had relations over a six-month period in 1987.

The court ruled that even if the girl had been infected with HIV, this could not be construed as "harmful" in the absence of an outbreak of AIDS. The court also declared that its ruling should not be allowed to set a precedent, stating that each case needs to be judged on its own merits. The Kempten public prosecutor, Walter Hofmaier, was dissatisfied with both the narrow scope of the ruling as well as the court's tacit approval of the couple's behaviour, and says he will appeal. The ruling, if it stands, might remove the legal basis for the prosecution of AIDS "desperadoes" who purposely try to infect others.

Hofmaier also says that the state is required to protect human life, and could not accept such careless and self-endangering behaviour on the part of an HIV carrier or his or her sexual partner. Suicide, however, is legal in West Germany.

A consensus is forming in Bavaria that a new law is needed to deal specifically with AIDS and virus carriers. So far, the government has prosecuted cases such as this one using laws regarding assault, attempted murder or the Federal Epidemic Law, as occurred in another recent case (see Nature 333, 585; 1988). Steven Dickman

were willing to take legal action. Following the death of its president, the association intends to redouble its efforts. But, as other countries have found, the question of eligibility for compensation is complex. Should awards be restricted to seropositive haemophiliacs, or extended to their wives and families? Should the size of awards reflect the victim's life expectancy? Should non-haemophiliacs infected by transfusion also be compensated?

Meanwhile the French blood transfusion society wants to encourage donors to give plasma, rather than blood. Plasma does not carry the same risks of infection and has a wider range of pharmaceutical applications.

Peter Cole 